\title{
In vivo anti-malarial activity of the hydroalcoholic extract of rhizomes of Kniphofia foliosa and its constituents
}

\author{
Yonatan Alebachew, Daniel Bisrat, Solomon Tadesse and Kaleab Asres* (i)
}

\begin{abstract}
Background: Kniphofia foliosa is a flamboyant robust perennial herb which has dense clumps and tick upright rhizomes with leaves at the base. In Ethiopia, it has several vernacular names including Abelbila, Ashenda, Amelmela, Yeznjero Ageda, Shemetmetie and Yezinjero Ageda. The plant is endemic to Ethiopian highlands, where its rhizomes are traditionally used for the treatment of malaria, abdominal cramps and wound healing. In the present study, the 80\% methanol extract of $K$. foliosa rhizomes and its constituents are tested against Plasmodium berghei in mice.

Methods: Isolation was carried out using column and preparative thin layer chromatography (PTLC). The chemical structures of the compounds were elucidated by spectroscopic methods (ESI-MS, 1D and 2D-NMR). Peters' 4-day suppressive test against $P$. berghei in mice was utilized for in vivo anti-malarial evaluation of the test substances.

Results: Two compounds, namely knipholone and dianellin were isolated from the $80 \%$ methanolic extract of $K$. foliosa rhizomes, and characterized. The hydroalcoholic extract $(400 \mathrm{mg} / \mathrm{kg})$ and knipholone $(200 \mathrm{mg} / \mathrm{kg})$ showed the highest activity with chemosuppression values of 61.52 and $60.16 \%$, respectively. From the dose-response plot, the median effective $\left(\mathrm{ED}_{50}\right)$ doses of knipholone and dianellin were determined to be 81.25 and $92.31 \mathrm{mg} / \mathrm{kg}$, respectively. Molecular docking study revealed that knipholone had a strong binding affinity to Plasmodium falciparum I-lactate dehydrogenase (pfLDH) target.
\end{abstract}

Conclusion: Results of the current study support the traditional use of the plant for the treatment of malaria.

Keywords: Kniphofia foliosa, Antimalarial activity, In vivo, Phenolic fractions, Plasmodium berghei, Knipholone, Dianellin

\section{Background}

Malaria is one of the most serious life-threatening infectious diseases [1]. It occurs mostly in poor tropical and subtropical areas of the world, where the Africa region accounted for $93 \%$ of all malaria cases and $94 \%$ of malaria deaths [2]. Most often, pregnant women and children under five years old are severely affected [3]. For instance, from the total deaths due to malaria in $2018,67 \%$ or

*Correspondence: kaleab.asres@aau.edu.et

Department of Pharmaceutical Chemistry and Pharmacognosy, School of Pharmacy, College of Health Sciences, Addis Ababa University, Addis Ababa, Ethiopia
272,000 were children under 5 years of age. That is nearly 745 children under age 5 daily or one child under five every two minutes dies of malaria in 2018 alone and most of these deaths occurred in sub-Saharan Africa [2]. In addition to funding shortfalls and fragile health systems, the major contributor to malarial morbidity and mortality is almost certainly the increasing resistance of malaria parasites to available drugs [4].

In Ethiopia, there has been success in the past recent years to reduce malaria burden. However, it is still prevalent in $75 \%$ of the country putting over 45 million people at risk [5]. The disease accounts for $7 \%$ of outpatient visits to health clinics and represents the third largest cause 
of morbidity [6]. In addition, $8 \%$ of global Plasmodium vivax malaria cases occur in Ethiopia [2]. Hence, the fight against malaria in Ethiopia remains a public health priority.

Natural products from plants have played a huge role throughout history in the fight against malaria. For instance, the aqueous extracts of cinchona bark were an effective anti-malarial preparation for more than 300 years [7]. Later, quinine, the major active alkaloid of cinchona was isolated in the 1820s. Similarly, artemisinin was isolated from the cold ether extracts of the leaves of Chinese traditional medicinal herb, Artemisia annua in 1972 [8]. Inspired by these, different classes of antimalarial compounds were isolated from a variety of plant families. Although hundreds of potent anti-malarial compounds were isolated from African traditional medicine, there has not been any clinically successful molecule [9-11].

The genus Kniphofia belongs to the family Asphodelaceae which comprises 70 species mainly confined to Africa [12]. Fifteen of these species have been recorded in Eastern Africa, of which five including Kniphofia foliosa are endemic to Ethiopia [13, 14]. The rhizomes of $K$. foliosa are traditionally used for the treatment of abdominal cramps, malaria and wounds [15]. Previously, six in vitro active anti-malarial compounds were isolated from roots of $K$. foliosa by Wube et al. [16] and Abdissa et al. [17]. In continuation of search for lead anti-malarial compounds from Ethiopian medicinal plants [18-20], the in vivo anti-malarial activity of the rhizomes of $K$. foliosa and its constituents are investigated.

\section{Methods}

\section{Chemicals and instruments}

Chromatographic separations were performed by analytical TLC on Silica gel 60 F254 (0.2 mm thick), Silica gel 60 (0.063-0.200 mm) for column chromatography (70-230 mesh) (Merck KGaA, Darmstadt, Germany) and solid phase separation on Isolute $\mathrm{C}_{18}$ columns $(10 \mathrm{~g}$; IST, Hengoed, UK). Trisodium citrate was obtained from $\mathrm{BDH}$ Chemicals Ltd, England, Giemsa was purchased from ESJAY Chemicals, Maharashtra 401,504, India, and pure chloroquine phosphate was supplied by Ethiopian Pharmaceutical Manufacturing Factory (EPHARM, Ethiopia).

NMR spectra were recorded at $500 \mathrm{MHz}$ for ${ }^{1} \mathrm{H}$ and $125 \mathrm{MHz}$ for ${ }^{13} \mathrm{C}$ on a Bruker Avance DMX400 FT-NMR spectrometer (Bruker, Billerica, Massachusetts, USA) using tetramethylsilane (TMS) as internal standard. All spectra were measured in $\mathrm{CDCl}_{3}$, except for compound 1, which was dissolved in $\mathrm{CD}_{3} \mathrm{OD}$. HRMS were determined on a Shimadzu LC-MS Advanced spectrometer (Shimadzu, Kyoto, Japan) in the positive and negative modes.

\section{Plant material}

The rhizomes of $K$. foliosa were collected in February 2017 from Mount Kundi near the city of Ankober in Shewa region of Central Ethiopia and identified by Professor Sebsibe Demisew at the National Herbarium, Addis Ababa University (AAU), Addis Ababa, Ethiopia, where voucher specimens were deposited (Collection number: YA01/2017).

\section{Experimental animals}

Healthy, 5-6 weeks old Swiss albino mice weighing 20-25 g were employed throughout the experiment. Female mice were used for acute toxicity study as per the OECD Guideline 425 [21], and either male or female mice were employed for the anti-malarial activity tests $[22,23]$. All mice used for the experiments were obtained either from the animal house of the School of Pharmacy (SoP), AAU or purchased from the Ethiopian Health Nutrition and Research Institute (EHNRI). The animals were maintained under natural lighting conditions $(12 \mathrm{~h}$ light and $12 \mathrm{~h}$ dark cycle) at room temperature and relative humidity of approximately $50 \%$. They were provided with food and water ad libitum and acclimatized for one week before the commencement of the experiment.

\section{Rodent parasite}

Chloroquine (CQ) sensitive ANKA strain of Plasmodium berghei was used. The donor mice infected with the parasite was obtained from the EHNRI. The parasites were maintained by serial blood passage from mouse to mouse at 5 days interval. All procedures followed were in accordance with the Guide for the Care and Use of Laboratory Animals [24] and were approved by the Institutional Review Board of the SoP, College of Health Sciences, AAU.

\section{Extraction, fractionation and isolation}

The air-dried powdered rhizomes of $K$. foliosa were soaked in $80 \%$ methanol at room temperature for 4 days with occasional shaking. Removal of the organic solvent using rotary evaporator (BUCHI Rotavapor ${ }^{\mathrm{TM}}$ R-300, Switzerland) followed by freeze drying of the remaining water extract yielded a dark red gummy solid. Portion of the dried extract was dissolved in $5 \% \mathrm{KOH}$ solution and partitioned with chloroform to remove the nonphenolic components. The aqueous phase was acidified with $2 \%$ $\mathrm{HCl}$ and then further partitioned with chloroform. The chloroform layer was collected and concentrated in a rotary evaporator to give a dried solid designated crude phenolic fraction I. The reddish solid mass (methanol soluble) formed between the acidified aqueous and chloroform layers was collected as phenolic fraction II. Purification of phenolic fraction I by preparative TLC 
(Additional file 1: Fig. S1) gave KFP-1 (18 mg, 0.048\%). Furthermore, portion of the hydroalcoholic extract was fractionated on silicagel flash column chromatography to yield three fractions. Fraction 1 was eluted with 100\% chloroform, fractions 2 and 3 with a mixture of chloroform and methanol (1:1), and fraction 4 with $100 \%$ methanol. Fraction 3 was concentrated and freeze dried to give viscous solid, which was further purified by sequential PTLC and solid phase extraction on Isolute $C_{18}$ columns to give YKFM-2 (14 mg, 0.04\%) (Additional file 1: Fig. S2).

\section{Acute oral toxicity testing}

Acute oral toxicity study was conducted as per the internationally accepted protocol of OECD Guideline 425 [21]. Fifteen healthy Swiss female albino mice weighing 20-25 g were randomly grouped into 3 each having 5 mice. Following 3-4 h of fasting (food only), one mouse from each group was orally administered $2000 \mathrm{mg} / \mathrm{kg}$ of the hydroalcoholic extract, KFP-1 and YKFM-2, consecutively. This was repeated on the remaining mice for the following four days. The mice were then observed individually for any physical or behavioural changes, such as loss of appetite, ruffled fur, lacrimation, mortality, and other signs of toxicity for $4 \mathrm{~h}$. The same procedure was followed for the remaining mice for the next five consecutive days and the results recorded. The follow-up observations were continued for all mice for 14 days.

\section{In vivo anti-malarial assay \\ Inoculation}

Blood smear was prepared on microscope slides from blood films taken from the donor (infected) mouse tail. The smear was fixed with methanol and stained with Giemsa to count the parasitaemia of the donor under a microscope (Primo Star, Carl Zeiss, Germany). The mice were then inoculated on day 0 with parasitized erythrocytes obtained from the donor by cardiac puncture using a sterile syringe when the parasitaemia level was $30-40 \%$. Blood from the donor was collected on a Petri dish containing $2 \%$ trisodium citrate and was immediately diluted with uninfected mouse blood and normal saline in such a way that the final volume contains $5 \times 10^{7}$ infected erythrocytes $/ \mathrm{ml}$ of blood. The diluted blood $(0.2 \mathrm{ml})$ was injected into all the experimental mice intraperitoneally (i.p) $[25,26]$.

\section{4-Day suppressive test}

The standard 4-day suppressive method was used for anti-malarial evaluation of the test substances [27]. The test was carried out in two phases. The extract and phenol fractions were evaluated in the first phase followed by KFP-1 and YKFM-2 in the second phase. Doses were selected based on the acute toxicity results whereby the middle dose was taken as one tenth of the limit dose which is $200 \mathrm{mg} / \mathrm{kg}$. The higher dose was twice $(400 \mathrm{mg} /$ $\mathrm{kg}$ ) the middle dose and the lower dose was one half $(100 \mathrm{mg} / \mathrm{kg})$ of the middle dose [28]. During the first phase, 60 inoculated mice were randomly grouped into 12 groups each having five mice. Groups 1 served as a negative control (distilled water, Vehicle1, $0.2 \mathrm{ml}$ ) for the extract and phenolic fraction 2 treated groups, while group 2 animals were used as a negative control (1\% tween 80 , Vehicle2, $0.2 \mathrm{ml}$ ) for phenolic fraction 1 treated group. The third group which served as a positive control was treated with standard pure chloroquine $(25 \mathrm{mg} / \mathrm{kg} /$ day). The remaining nine groups were treatment groups and received 100, 200, and $400 \mathrm{mg} / \mathrm{kg} /$ day of the hydroalcoholic extract and the two phenol fractions. The dosage regimen for the pure compounds was chosen from the preliminary test results obtained from experiments carried out on a few mice. Similarly, during evaluation of KPF-1 and YKFM-2, 45 inoculated mice were randomly grouped into 9 groups, each containing five mice. The first two groups were negative controls (distilled water, Vehicle3, $0.2 \mathrm{ml}$ ) and positive controls (standard pure chloroquine, $25 \mathrm{mg} / \mathrm{kg} /$ day). The rest of the groups were treatment groups and received KFP-1 $(25,50,100$ and $200 \mathrm{mg} / \mathrm{kg} /$ day $)$ and YKFM-2 (25, 50, $100 \mathrm{mg} / \mathrm{kg} /$ day $)$. All the test substances were administered orally using oral gavage. Treatment was started $3 \mathrm{~h}$ post-infection (p.i) on day 0 and continued daily for the next 3 days (i.e. from day 0 to day 3). On the fifth day (or day 4), two Giemsastained blood smears were prepared from each mice to count the number of parasites under the microscope (Primo Star, Carl Zeiss, Germany) with an oil immersion objective of $100 \times$ magnification power [21, 23, 29].

Mean percent parasitaemia and percent suppression were calculated using the following formulae.

$$
\% \text { Parasitaemia }=\left(\frac{\text { Number of parasitized RBC }}{\text { Total number of RBC count }}\right) \times 100
$$

$$
\% \text { Suppression }=\left(\frac{\text { Mean parasitaemia of negative control }- \text { Mean parasitaemia of treated }}{\text { Mean parasitaemia of negative control }}\right) \times 100
$$




\section{Body weight and survival time measurements}

Body weight of each mouse was measured on day 0 before infection and on day 4 . Survival time was recorded from day 1 to day 28 post inoculation. Then, the mean body weight and mean survival time were calculated for each group [20].

\section{Molecular docking study}

Docking study was carried out on two crystal structures of Plasmodium enzymes plasmepsin II (Protein Data Bank; PDB: 4CKU) and l-lactate dehydrogenase (pfLDH) [PDB: 1LDG], using SeeSar10.0 software (BioSolveIT, Sankt Augustin, Germany). For plasmepsin II, the selected binding site was the binding pocket of a previously designed inhibitor P2FE-400, 5-(1,1-dioxido-1,2-thiazinan-2yl)-N1-((2S,3R)-3-hydroxy-4-((2-(3-methoxyphenyl) propan-2-yl)amino)-1-phenylbutan-2-yl)-N3,N3-dipropylisophthalamide; while for pfLDH, the cofactor nicotinamide adenine dinucleotide (NADH) binding site was selected for docking. The HYDE score was used to estimate the binding affinity of the molecules [30,31].

\section{Statistical analysis}

Data analysis was carried out using IBM SPSS (Statistical Package for Social Sciences) Statistics for Windows, Version 20.0. Armonk, NY: IBM Corp. Results were expressed as mean \pm standard error of mean $(M \pm S E M)$. The statistical significance was determined by one-way ANOVA followed by Tukey post hoc test to compare percent suppression (activity), mean survival time and percent changes in body weight of the $P$. berghei infected mice among the treatment and control groups. $P<0.05$ was considered significant.

\section{Results and discussion}

\section{Structural elucidation of the isolated compounds}

Phytochemical investigation of the rhizome extract of $K$. folosia over silica gel column and PTLC resulted in the isolation of two compounds. Compound 1 (YKFM-2): $\mathrm{R}_{\mathrm{f}}: 0.69$ (a mixture of EtOAc and $n$-butanol-acetic acidwater, upper phase; 4:1:5 in a ratio of 1:1); compound 2 (KFP-1) R $\mathrm{f}_{\mathrm{f}} 0.47$ (toluene/EtOAc; 5:1).

Compound $\mathbf{1}$ was obtained as a light red amorphous solid. The positive high resolution-ESI mass spectrum gave a pseudomolecular ion at $m / z 547.1619[\mathrm{M}+\mathrm{Na}]^{+}$ (calcd. $m / z 547.1791[\mathrm{M}+\mathrm{Na}]^{+}$, corresponding to a molecular formula $\mathrm{C}_{25} \mathrm{H}_{32} \mathrm{O}_{12}$. In the ${ }^{1} \mathrm{H}$ NMR spectrum, four proton signals which resonated at $\delta 7.12(s, \mathrm{H}-4)$, $7.28(1 \mathrm{H}, d d, J=1.3,7.3 \mathrm{~Hz}, \mathrm{H}-7), 7.36(1 \mathrm{H}, d, J=8.2 \mathrm{~Hz}$, $\mathrm{H}-6)$ and $7.40(1 \mathrm{H}, d d, J=1.3,8.2 \mathrm{~Hz}, \mathrm{H}-5)$ indicated the presence of aromatic ring moiety. Three of these proton signals which are multiplets imply that they are found in close proximity (or are adjacent) and the fourth singlet aromatic proton peak at $\delta 7.12(s, \mathrm{H}-4)$ provides clues for the presence of a fused aromatic ring system. The presence of a disaccharide unit in compound 1 was revealed by the typical anomeric proton signals at $\delta 3.31(1 \mathrm{H}$, $\left.m, \mathrm{H}-4^{\prime \prime}\right)$ and $5.05\left(1 \mathrm{H}, d, J=7.9 \mathrm{~Hz}, \mathrm{H}-1^{\prime}\right)$. The proton peaks from $\delta 5.05$ to 2.91 further justify the presence of a disaccharide moiety. The ${ }^{13} \mathrm{C}$ spectrum region from $\delta$ 76.82 to 66.59 also confirmed that the compound contains a disaccharide moiety. In addition, the two elevated ${ }^{13} \mathrm{C}$ sugar signals at $\delta 102.84$ and 100.86 indicate that the sugar units are linked through acetal bond. Furthermore, the absence of one $\mathrm{CH}$ signal in the sugar region ( $\delta 76.82-\delta 66.59$ ) suggests one of the sugar units to be rhamnose. And this was found to be in good agreement with ${ }^{13} \mathrm{C}$ NMR reports of similar glycosides [32, 33]. Hence, the disaccharide moiety was confirmed to be rhamnose-glucose 1,6 linkage. In addition, the presence of $10{ }^{13} \mathrm{C}$ signals from $\delta 154.71$ to $\delta 110.5$ implies that the fused aromatic ring system is naphthalene. Six of these carbon signals are absent from DEPT spectrum indicating they are quaternary aromatic carbons. Besides, two of them are elevated ( $\delta 154.71$ and $\delta 151.49)$ suggesting that they are oxygenated quaternary aromatic carbons. On the other hand, the two less elevated $(\delta 136.74$ and $\delta$ 113.54) quaternary aromatic carbons are the bridgehead carbons of the fused aromatic system [33]. The remaining two quaternary aromatic carbon signals resonated at $\delta 124.73(\mathrm{C}-2)$ and $\delta 133.30(\mathrm{C}-3)$. Lastly, the ${ }^{13} \mathrm{C}$ signals at 207.7 and 41.3 are the carbonyl carbon and its acetyl methyl. Therefore, based on the above evidence and in comparison with ${ }^{1} \mathrm{H}$ and ${ }^{13} \mathrm{C}$ NMR data of the same and related compounds [33, 34], the structure of compound 1 was determined to be dianellin or 1-(1-hydroxy-3-methyl-8- $(((2 \mathrm{~S}, 3 \mathrm{R}, 4 \mathrm{~S}, 5 \mathrm{~S}, 6 \mathrm{R}) 3,4,5$-trihydroxy-6-((((2S,3S,4S, 5S ,6R)3,4,5-trihydroxy-6methyltetrahydro-2H-pyran-2-yl)oxy)methyl)tetrahydro2H-pyran-2yl)oxy)naphthalen-2-yl) ethanone (Fig. 1). Table 1 summarizes the NMR data of compound $\mathbf{1}$.

Compound 2 was isolated as an orange colored amorphous solid. The molecular formula was determined to be $\mathrm{C}_{24} \mathrm{H}_{18} \mathrm{O}_{8}$ by the positive-ion ESIMS $(\mathrm{m} / z 458.21$ $[\mathrm{M}+\mathrm{Na}]^{+}$), which was also consistent with ${ }^{1} \mathrm{H}$ and ${ }^{13} \mathrm{C}$ NMR spectral data. The chelated hydroxyl protons shown as singlet peaks at $\delta 12.6(1 \mathrm{H}, s,-\mathrm{OH}, \mathrm{H}-1)$ and $11.9(1 \mathrm{H}$, $s,-\mathrm{OH}, \mathrm{H}-8)$ and the typical $\mathrm{ABC}$ pattern of the proton peaks at $\delta 7.57(1 \mathrm{H}, d d, J=8,7 \mathrm{~Hz}, \mathrm{H}-6), 7.55(1 \mathrm{H}, d d$, $J=7,1.5 \mathrm{~Hz}, \mathrm{H}-5), 7.21(1 \mathrm{H}, d d, J=8,1.5 \mathrm{~Hz}, \mathrm{H}-7)$ indicate the presence of chrysophanol moiety. Besides, the singlet aromatic proton signal present at $\delta 7.28$ suggests that it is found adjacent to a substituted aromatic carbon. The ${ }^{13} \mathrm{C}$ and DEPT spectra of compound 2 also support the presence of chrysophanol moiety [35, 36]. Moreover, from the ${ }^{13} \mathrm{C}$ spectrum, additional aromatic carbon 
Table $1{ }^{1} \mathrm{H}$ and ${ }^{13} \mathrm{C}$ NMR data of compound 1 measured in methanol- $d_{4}$

\begin{tabular}{|c|c|c|c|c|}
\hline \multicolumn{3}{|c|}{ Present data } & \multicolumn{2}{|c|}{ Reference data [33] } \\
\hline Position & $\delta_{c}(p p m)$ & $\delta_{H}(p p m)$ & $\delta_{c}(p p m)$ & $\delta_{H}(p p m)$ \\
\hline 1 & 151.49 & - & 150.2 & - \\
\hline 2 & 124.73 & - & 125.2 & - \\
\hline 3 & 133.30 & - & 132.8 & - \\
\hline 4 & 119.58 & $7.12(1 \mathrm{H}, \mathrm{s})$ & 119.4 & $7.21(1 \mathrm{H}, \mathrm{s})$ \\
\hline 5 & 122.58 & $7.40(1 \mathrm{H}, d d, J=1.3,8.2 \mathrm{~Hz})$ & 122.3 & $7.47(1 \mathrm{H}, d d, J=1.0,8.0 \mathrm{~Hz})$ \\
\hline 6 & 127.20 & $7.36(1 \mathrm{H}, d, J=8.2 \mathrm{~Hz})$ & 127.3 & $7.40(1 \mathrm{H}, d d, J=8.0,8.0 \mathrm{~Hz})$ \\
\hline 7 & 110.51 & $7.28(1 \mathrm{H}, d d, J=1.3,7.3, \mathrm{~Hz})$ & 110.7 & $7.30(1 \mathrm{H}, d d, J=1.0,8.0 \mathrm{~Hz})$ \\
\hline 8 & 154.71 & - & 154.2 & - \\
\hline 9 & 113.54 & - & 113.2 & - \\
\hline 10 & 136.74 & - & 135.7 & - \\
\hline $1^{\prime}$ & 102.84 & $5.05(1 \mathrm{H}, d, J=7.9 \mathrm{~Hz})$ & 102.6 & $5.04(1 \mathrm{H}, d, J=7.5 \mathrm{~Hz})$ \\
\hline $2^{\prime}$ & 73.57 & $3.46(1 \mathrm{H}, t, J=8.8 \mathrm{~Hz})$ & 73.3 & $3.39(1 \mathrm{H}, \mathrm{m})$ \\
\hline $3^{\prime}$ & 76.82 & $3.37(1 \mathrm{H}, \mathrm{m})$ & 76.2 & $3.36(1 \mathrm{H}, \mathrm{m})$ \\
\hline $4^{\prime}$ & 70.13 & $2.91(1 \mathrm{H}, m)$ & 70.1 & $3.18(1 \mathrm{H}, m)$ \\
\hline $5^{\prime}$ & 76.10 & $3.68(1 \mathrm{H}, m)$ & 76.0 & $3.59(1 \mathrm{H}, \mathrm{m})$ \\
\hline $6^{\prime}$ & 66.59 & $4.05(1 \mathrm{H}, d, J=8.9 \mathrm{~Hz}) ; 3.63(1 \mathrm{H}, m)$ & 66.6 & $\begin{array}{l}3.93(1 \mathrm{H}, d d, J=1.5 \\
11.0 \mathrm{~Hz}) ; 3.50(2 \mathrm{H}, \mathrm{m})\end{array}$ \\
\hline $1^{\prime \prime}$ & 100.86 & $4.71(1 \mathrm{H}, d, J=1.4 \mathrm{~Hz})$ & 100.7 & $4.62(1 \mathrm{H}, d, J=1.5 \mathrm{~Hz})$ \\
\hline $2^{\prime \prime}$ & 70.84 & $3.84(1 \mathrm{H}, d d, J=1.6,3.4 \mathrm{~Hz})$ & 70.4 & $3.68(1 \mathrm{H}, \mathrm{m})$ \\
\hline $3^{\prime \prime}$ & 71.03 & $3.63(1 \mathrm{H}, \mathrm{m})$ & 70.7 & $3.50(2 \mathrm{H}, m)$ \\
\hline $4^{\prime \prime}$ & 72.59 & $3.31(1 \mathrm{H}, m)$ & 71.9 & $3.20(1 \mathrm{H}, m)$ \\
\hline $5^{\prime \prime}$ & 68.55 & $3.52(1 \mathrm{H}, \mathrm{m})$ & 68.4 & $3.49(1 \mathrm{H}, \mathrm{m})$ \\
\hline $6^{\prime \prime}$ & 16.55 & $1.17(3 \mathrm{H}, d, J=6.2 \mathrm{~Hz})$ & 17.7 & $1.12(3 \mathrm{H}, d, J=6.0 \mathrm{~Hz})$ \\
\hline $\mathrm{ArCH} \underline{H}_{3}$ & 18.49 & $2.25(3 \mathrm{H}, \mathrm{s})$ & 19.0 & $2.25(3 \mathrm{H}, \mathrm{s})$ \\
\hline $\mathrm{COCH}_{3}$ & 41.3 & $2.97(3 \mathrm{H}, \mathrm{s})$ & 31.9 & $2.52(3 \mathrm{H}, \mathrm{s})$ \\
\hline $\mathrm{COCH}_{3}$ & 207.07 & - & 204.4 & - \\
\hline
\end{tabular}

$s$, singlet, $d$, doublet, $d d$, doublet of doublets, $m$, multiplet, $b r$, broad, $t$, triplet

signals at $\delta 152.44,132.72,125.75,125.31$, and 120.11 together with the ${ }^{1} \mathrm{H}$ peaks at $14.3(s, \mathrm{OH}), 6.19$ (s, aromatic $\mathrm{H}), 5.7(s(b r), \mathrm{OH})$ and $3.91\left(s, \mathrm{OCH}_{3}\right)$ indicate the attachment of a methyl etherified acetylphloroglucinol moiety to chrysophanol. These data in comparison with the reported ${ }^{1} \mathrm{H}$ and ${ }^{13} \mathrm{C}$ NMR results identify compound 2 as knipholone (Fig. 1). Table 2 summarizes the NMR data of compounds 2 .

\section{Acute oral toxicity}

Acute oral toxicity test results of this study documented that the $80 \%$ methanol extract of $K$. foliosa, knipholone and dianellin were safe at a dose of $2000 \mathrm{mg} / \mathrm{kg}$ [21, 37]. After $72 \mathrm{~h}$, the animals tolerated the administered dose although immediate mild toxicity signs such as ruffled fur, loss of appetite and slight sleepiness, which disappeared few hours after administration were observed. Also, there was no mortality within 14 days of observation which entails that the $\mathrm{LD}_{50} \mathrm{~s}$ of the extract, knipholone and dianellin are above $2000 \mathrm{mg} / \mathrm{kg}$.

\section{Anti-malarial activity of the hydroalcoholic extract}

The $80 \%$ methanol extract of $K$. folosia showed chemosuppressive effect against $P$. berghei in mice (Table 3). At all dose levels tested, the extract exhibited a statistically significant $(p<0.001)$ dose dependent effect. The extract showed the highest activity with 61.52 and $51.39 \%$ suppression at 400 and $200 \mathrm{mg} / \mathrm{kg}$, respectively. Moreover, at doses of 200 and $400 \mathrm{mg} / \mathrm{kg}$, the extract significantly extended the survival days of treated groups compared to the negative controls, indicating that the extract has the capacity to lower the overall pathologic effect of the parasite in mice. However, there was no significant difference in percent change in weight before and after treatment among groups except with the positive control group. According to Deharo et al. [38], anti-malarial activity of the $80 \%$ methanol extract of $K$. folosia can be regarded 
Table $2{ }^{1} \mathrm{H}$ and ${ }^{13} \mathrm{C}$ NMR data of compounds 2 in chloroform-d

\begin{tabular}{|c|c|c|c|c|}
\hline \multicolumn{3}{|c|}{ Present data } & \multicolumn{2}{|c|}{ Reference data [35] } \\
\hline Position & $\delta_{C}(p p m)$ & $\delta_{H}(p p m)$ & $\delta_{\mathrm{C}}(\mathrm{ppm})$ & $\delta_{H}(p p m)$ \\
\hline 1 & 161.69 & $12.6(1 \mathrm{H}, \mathrm{s},-\mathrm{OH})$ & 161.7 & $12.53(1 \mathrm{H}, \mathrm{s},-\mathrm{OH})$ \\
\hline $1 \mathrm{a}$ & 115.22 & - & 114.7 & - \\
\hline 2 & 125.31 & $7.28(1 \mathrm{H}, \mathrm{s})$ & 124.6 & $7.32(1 \mathrm{H}, q, J=0.7 \mathrm{~Hz})$ \\
\hline 3 & 152.44 & - & 151.6 & \\
\hline 4 & 125.75 & - & 128.5 & \\
\hline $4 a$ & 132.72 & - & 131.6 & \\
\hline 5 & 120.11 & $7.55(1 \mathrm{H}, d d, J=1.5,7 \mathrm{~Hz})$ & 119.3 & $7.56(1 \mathrm{H}, d d, J=1.5,7 \mathrm{~Hz})$ \\
\hline $5 a$ & 134.27 & - & 134.4 & \\
\hline 6 & 137.12 & $7.57(1 \mathrm{H}, d d, J=7,8 \mathrm{~Hz})$ & 137.4 & $7.75(1 \mathrm{H}, d d, J=7,8 \mathrm{~Hz})$ \\
\hline 7 & 123.85 & $7.21(1 \mathrm{H}, d d, J=1.5,8 \mathrm{~Hz})$ & 123.3 & $7.30(1 \mathrm{H}, d d, J=1.5,8 \mathrm{~Hz})$ \\
\hline 8 & 159.51 & $11.9(1 \mathrm{H}, \mathrm{s},-\mathrm{OH})$ & 161.1 & $12.0(1 \mathrm{H}, \mathrm{s},-\mathrm{OH})$ \\
\hline $8 a$ & 115.37 & - & 115.5 & - \\
\hline 9 & 192.68 & - & 192.5 & - \\
\hline 10 & 182.66 & - & 181.9 & - \\
\hline $1^{\prime}$ & 106.07 & - & 104.7 & - \\
\hline $2^{\prime}$ & 163.27 & $5.7(1 \mathrm{H}, \mathrm{s}(b r),-\mathrm{OH})$ & 163.3 & $8.95(1 \mathrm{H}, \mathrm{s}(b r),-\mathrm{OH})$ \\
\hline $3^{\prime}$ & 107.14 & - & 107.3 & - \\
\hline $4^{\prime}$ & 163.07 & - & 162.4 & - \\
\hline $5^{\prime}$ & 90.61 & $6.19(1 \mathrm{H}, \mathrm{s})$ & 91.2 & $6.24(1 \mathrm{H}, \mathrm{s})$ \\
\hline $6^{\prime}$ & 162.85 & $14.3(1 \mathrm{H}, \mathrm{s},-\mathrm{OH})$ & 161.9 & - \\
\hline $\mathrm{ArCH}_{3}$ & 21.02 & $2 . .21(3 \mathrm{H}, \mathrm{s})$ & 20.4 & $2.17(3 \mathrm{H}, d, J=0.7 \mathrm{~Hz})$ \\
\hline $\mathrm{OCH}_{3}$ & 55.56 & $3.91(3 \mathrm{H}, \mathrm{s})$ & 55.6 & $3.98(3 \mathrm{H}, \mathrm{s})$ \\
\hline $\mathrm{COCH}_{3}$ & 33.14 & $2.70(3 \mathrm{H}, \mathrm{s})$ & 32.6 & $2.62(3 \mathrm{H}, \mathrm{s})$ \\
\hline $\mathrm{COCH}_{3}$ & 202.3 & - & 202.3 & - \\
\hline
\end{tabular}

$s$, singlet, $d$, doublet, $d d$, doublet of doublets, $q$, quartet, $m$, multiplet, $b r$, broad

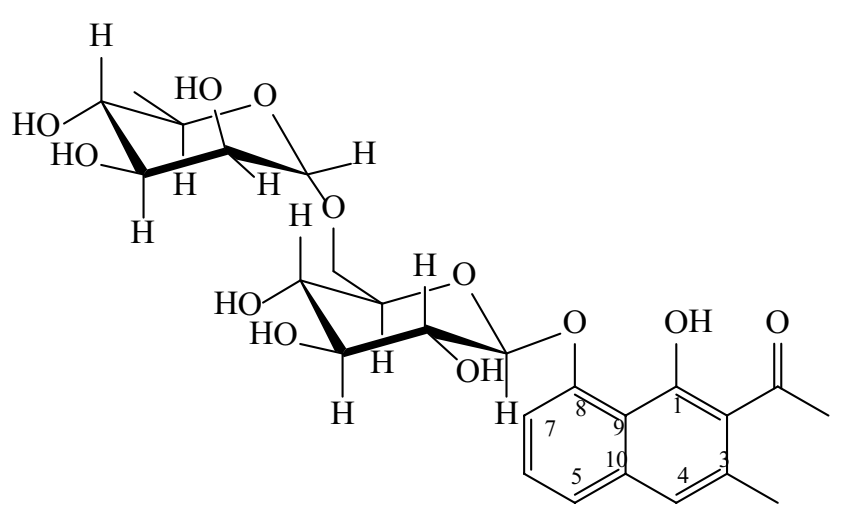

1

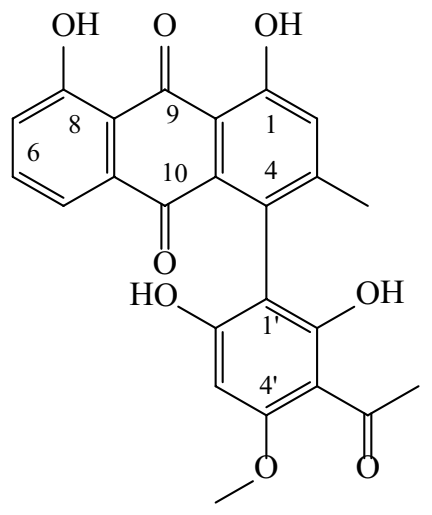

2

Fig. 1 Chemical structures of dianellin (1) and knipholone (2)

as good since it showed greater than $50 \%$ suppression at a dose of $200 \mathrm{mg} / \mathrm{kg}$. Previous studies demonstrated that medicinal plants rich in anthraquinones such as aloes and senna possess notable in vivo anti-malarial activity $[39,40]$. 
Table 3 Anti-malarial activity of the $\mathbf{8 0 \%}$ rhizome extract of Kniphofia folosia in mice infected with Plasmodium berghei

\begin{tabular}{llccc}
\hline Test substances & Dose $(\mathbf{m g} / \mathbf{k g} /$ day) & Percent parasitaemia & Percent suppression & Mean survival time (in days) \\
\hline Vehicle1 & $0.2 \mathrm{ml}$ & $35.9860 \pm 1.22034$ & 0.0000 & $6.0000 \pm 0.31623$ \\
KF100 & $100 \mathrm{mg}$ & $24.2100 \pm 1.18037$ & $32.7200^{\mathrm{a}^{*} \mathrm{c}^{* *} \mathrm{~d}^{*} \mathrm{e}^{*}}$ & $9.4000 \pm 0.50990^{\mathrm{a}^{* *} \mathrm{e}^{*}}$ \\
KF200 & $200 \mathrm{mg}$ & $17.4920 \pm 0.67964$ & $51.3900^{\mathrm{a}^{*} \mathrm{~b}^{* *} \mathrm{e}^{*}}$ & $9.6000 \pm 0.92736^{a^{*} \mathrm{e}^{*}}$ \\
KF400 & $13.8480 \pm 0.76024$ & $61.5200^{\mathrm{a}^{*} \mathrm{~b}^{*} \mathrm{e}^{*}}$ & $8.4000 \pm 0.24495^{\mathrm{e}^{*}}$ \\
Chloroquine & $400 \mathrm{mg}$ & $0.0140 \pm 0.00600$ & $99.8000^{\mathrm{a}^{*}}$ & $27.2000 \pm 0.58310^{\mathrm{a}^{*} \mathrm{~b}^{*} \mathrm{c}^{*} \mathrm{~d}^{*}}$
\end{tabular}

Values are presented as mean $\pm \mathrm{SEM} ; \mathrm{n}=5 ;{ }^{\mathrm{a}} \mathrm{Compared}$ to vehicle1 (distilled water), ${ }^{\mathrm{b}} \mathrm{compared}$ to $\mathrm{KF} 100,{ }^{\mathrm{C}} \mathrm{Compared}$ to $\mathrm{KF} 200,{ }^{\mathrm{d}} \mathrm{Compared}$ to $\mathrm{KF} 400,{ }^{\mathrm{e}} \mathrm{Compared}$ to chloroquine; ${ }^{*}(p<0.001) ;{ }^{* *}(p<0.01) ; K F=80 \%$ extracts of $K$. folosia, numbers refer to doses in $\mathrm{mg} / \mathrm{kg} / \mathrm{day}$

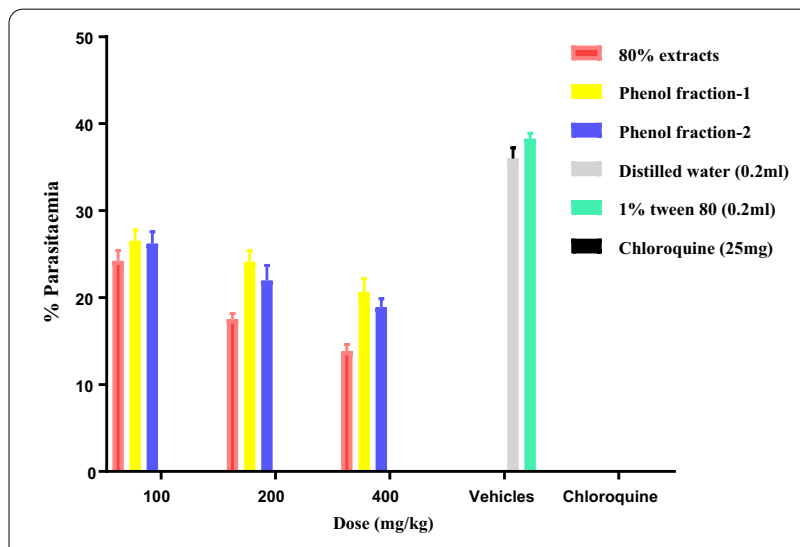

Fig. 2 Anti-malarial activity of the $80 \%$ extract and phenol fractions of rhizomes of Kniphofia folosia in mice infected with Plasmodium berghei in 4-day suppression test. Values are presented as mean $\pm S E M ; n=5$

\section{Anti-malarial activity of the phenol fractions and their constituents}

The two phenolic fractions of $K$. folosia were also found to have activity against $P$. berghei in mice (Fig. 2). Compared to their respective negative controls, both factions possessed significant suppressive activity at all dose levels tested. They showed the highest activity at $400 \mathrm{mg} / \mathrm{kg}$ with fraction 1 and fraction 2 causing $46.32 \%$ and $47.53 \%$ suppression, respectively. Both fractions prolonged the mean survival days of the treatment groups by 2 days relative to their negative controls although it was not statistically significant. No significant difference in percent change in weight was noted in the treatment groups when compared with the positive controls. Therefore, it can be deduced that the phenolic fractions of $K$. folosia are moderate in their in vivo anti-malarial activity, congruent with earlier reports that extracts containing phenolic compounds and their glycosides have modest levels of antiplasmodial activity [41-43].

Among the isolated compounds, knipholone displayed the strongest anti-malarial activity against $P$. berghei infected mice (Table 4). Although knipholone and dianellin showed significant suppression at all dose levels tested, the former displayed superior activity with percent suppression values of 55.14 and $60.16 \%$ at doses of 100 and $200 \mathrm{mg} / \mathrm{kg}$, respectively. Moreover, it significantly prolonged the mean survival days of the treatment groups (Table 4). The dose-response plot (Fig. 3) disclosed that the $\mathrm{ED}_{50}$ values of knipholone and dianellin were 81.25 and $92.31 \mathrm{mg} / \mathrm{kg}$, respectively. However,

Table 4 Anti-malarial activity of knipholone and dianellin in mice infected with Plasmodium berghei

\begin{tabular}{|c|c|c|c|c|}
\hline Test substances & Dose (mg/kg/day) & Percent parasitaemia & Percent suppression & Mean survival time (in days) \\
\hline \multirow[t]{5}{*}{ Vehicle3 Knipholone } & $0.2 \mathrm{ml}$ & $46.3560 \pm 1.46925$ & 0.0000 & $6.4000 \pm 0.50990$ \\
\hline & $25 \mathrm{mg}$ & $30.5440 \pm 1.45634$ & $34.1200^{a^{*} d^{*} e^{*} h^{*} i^{*}}$ & $8.8000 \pm 0.37417^{i^{*}}$ \\
\hline & $50 \mathrm{mg}$ & $26.2640 \pm 1.80001$ & $42.6400^{a^{*} e^{* *} h^{* *}}$ & $9.0000 \pm 0.54772^{i *}$ \\
\hline & $100 \mathrm{mg}$ & $20.7940 \pm 0.91475$ & 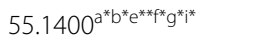 & $9.2000 \pm 0.73485^{a^{* * * * *}}$ \\
\hline & $200 \mathrm{mg}$ & $18.4680 \pm 0.97391$ & 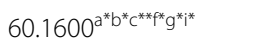 & $9.4000 \pm 0.24495^{\mathrm{a}^{* * * *}}$ \\
\hline \multirow[t]{3}{*}{ Dianellin } & $25 \mathrm{mg}$ & $32.5280 \pm 0.96771$ & $29.8300^{\mathrm{a}^{*} C^{*} \mathrm{~d}^{*} \mathrm{e}^{*} \mathrm{~h}^{*} \mathrm{~h}^{*} \mathrm{i}^{*}}$ & $7.6000 \pm 0.24495^{i^{*}}$ \\
\hline & $50 \mathrm{mg}$ & $25.9408 \pm 0.77243$ & $44.0400^{a^{*} d^{*} e^{*} g^{*} h^{*} i^{*}}$ & $8.2000 \pm 0.37417^{i *}$ \\
\hline & $100 \mathrm{mg}$ & $21.4303 \pm 0.84156$ & $53.7700^{a^{*} b^{*} c^{*} f q^{*} j^{* *}}$ & $8.2000 \pm 0.37417^{i^{*}}$ \\
\hline Chloroquine & $25 \mathrm{mg}$ & $0.0140 \pm 0.00600$ & $9.8000^{a-h^{*}}$ & $27.4000 \pm 0.400000^{a-h^{*}}$ \\
\hline
\end{tabular}

Values are presented as mean $\pm \mathrm{SEM} ; \mathrm{n}=5 ;{ }^{\mathrm{a}}$ compared to vehicle3 (distilled water), ${ }^{\mathrm{b}}$ compared to knipholone $25 \mathrm{mg},{ }^{\mathrm{c}} \mathrm{compared}$ to $\mathrm{knipholone} 50 \mathrm{mg},{ }^{\mathrm{d}} \mathrm{Compared}$ to knipholone $100 \mathrm{mg}$, ${ }^{\mathrm{e}}$ compared to knipholone $200 \mathrm{mg},{ }^{\mathrm{f}}$ compared to dianellin $25 \mathrm{mg},{ }^{\mathrm{g}} \mathrm{compared}$ to dianellin $50 \mathrm{mg}$, ${ }^{\mathrm{h}}$ compared to dianellin $100 \mathrm{mg}$, ${ }^{\mathrm{i}}$ compared to chloroquine; ${ }^{*}(\mathrm{p}<0.001) ;^{* *}(\mathrm{p}<0.01) ;^{* * *}(\mathrm{p}<0.05)$; numbers refer to doses in $\mathrm{mg} / \mathrm{kg} / \mathrm{day}$ 


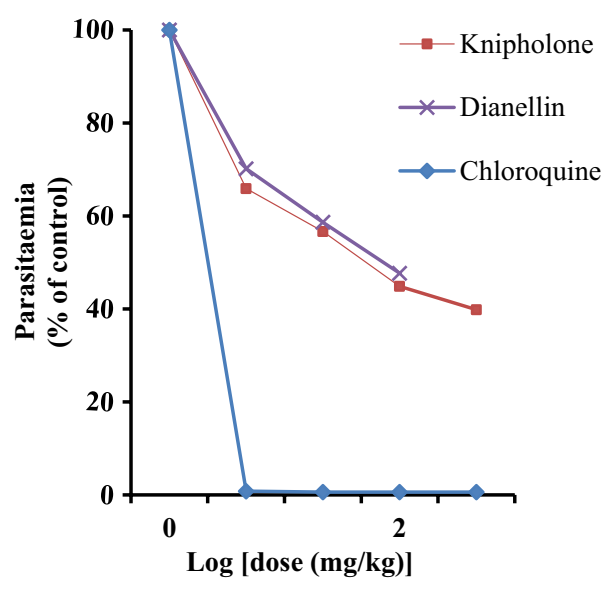

Fig. 3 Anti-malarial activity of knipholone and dianellin in mice infected with Plasmodium berghei. The $\mathrm{ED}_{50}$ was estimated from a plot of log dose against parasitaemia (expressed as a percentage of the control). Values are presented as mean $\pm S E M ; n=5$

neither of the compounds caused significant difference in percent change of weight among the treated groups.

Previously, the methanol and dichloromethane extracts of $K$. folosia as well as dimeric anthraquinones, knipholone and dianellin isolated therefrom have been shown to have in vitro activity against chloroquineresistant (W2) and chloroquine-sensitive (D6 and 3D7) strains of $P$. falciparum $[16,17]$. The $\mathrm{ED}_{50}$ of knipholone $(1.49 \mu \mathrm{g} / \mathrm{ml})$ against 3D7 strains [16] was much lower than that of dianellin which showed $\mathrm{IC}_{50}$ values of 3.14 and $5.47 \mu \mathrm{g} / \mathrm{ml}$ against $\mathrm{W} 2$ and D6 strains, respectively [17]. In addition, knipholone isolated from Bulbine capitata and Bulbine frutescens has been reported to possess in vitro activity against chloroquine-resistant (K1) and chloroquine-sensitive (NF54) strains with $\mathrm{IC}_{50}$ values of 1.06 and $1.7 \mu \mathrm{M}$, respectively [44, 45].

In this study, the acute toxicity as well as the in vivo antiplasmodial activities of the various extracts of $K$. folosia and its major constituents was evaluated against P. berghei in mice. Since members of the genus Kniphofia have been documented to produce anthraquinones and related phenols [46, 47], the total extract was further fractionated into phenolic and nonphenolic fractions. Results of the current study demonstrated that the hydroalcoholic extract, the fractions as well as the isolated compounds significantly suppressed parasitaemia indicating that they possesses blood schizonticidal activity on early infection of mice with $P$. berghei. The results also revealed that the in vivo $\mathrm{ED}_{50}$ values of knipholone $(81.25 \mathrm{mg} / \mathrm{kg})$ and dianellin $(92.31 \mathrm{mg} / \mathrm{kg})$ correlate well with their reported in vitro activities. After 4 days of treatment with different doses of knipholone and dianellin, there were significant differences in percent parasite suppression among the treatment groups. However, there was no significant change in mean survival time among mice administered with different doses of knipholone and dianellin except that the animals which received 100 and $200 \mathrm{mg} / \mathrm{kg}$ of knipholone survived longer than those given $25 \mathrm{mg} / \mathrm{kg}$ of the compound. This is an indication that the different doses of the test compounds have the same effect on overall pathologic effect of the parasite in mice concurrent with previous results obtained for the crude extract and solvent fractions of Strychnos mitis leaves [23]. To the best of our knowledge, this is the first report on acute toxicity and in vivo anti-malarial evaluation of $K$. folosia and its constituents.

Perusal of literature reveals that a number of promising anthraquinones and preanthraquinones leads such
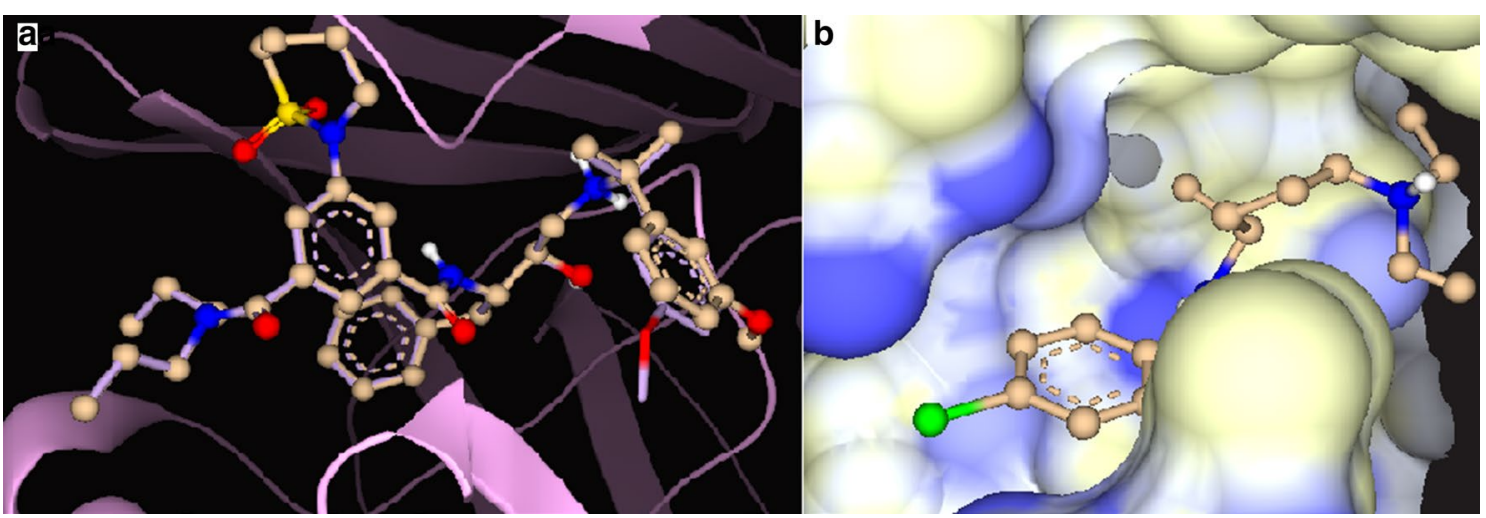

Fig. 4 a Superimposition of redocked P2FE-400 (shown as a solid line) with its original position (shown in ball-stick model) as a complex (co-crystal) in the binding site of the crystal structure of plasmepsin II (PDB 4cku). b Surface representation showing chloroquine in the binding site of plasmepsin II with lipophilicity coloring, white representing hydrophobic pockets and blue representing hydrophilic pockets. Chloroquine is shown in ball-stick model 

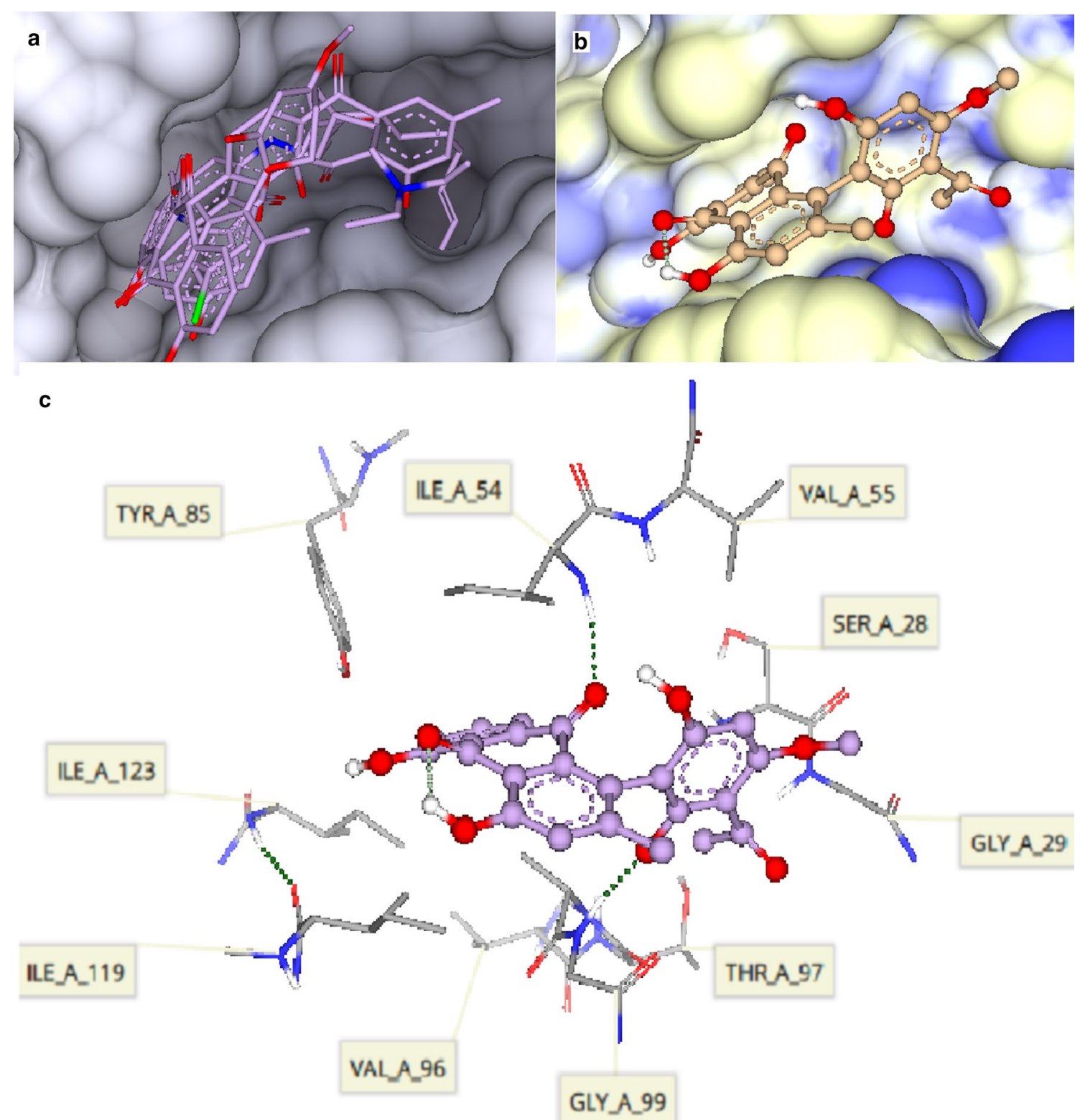

Fig. 5 a Surface representation showing the superimposed compounds in the binding site of Plasmodium falciparum I-lactate dehydrogenase (pfLDH) (PDB1ldg). b Surface representation showing knipholone in the binding site of pfLDH with lipophilicity coloring, white representing hydrophobic pockets and blue representing hydrophilic pockets. Knipholone is shown in ball-stick model. c Binding interaction of knipholone with amino acid residues of pfLDH

as visimione, rufigallol, uveoside, aloin and phenyl anthraquinones have been isolated and/or synthesized [16, 48-50]. These compounds are considered as oxidants like artemisinins and 4-aminoquinolines. More importantly, they are catalytic oxidants that enhance the production of reactive oxygen species (ROS) inside parasitized erythrocytes or increase these cells' susceptibility to oxygen radicals. The free oxygen radicals formed interact with haem or other biomolecular targets inhibiting its tetramerization to the insoluble haemozoin (malaria pigment) [51, 52]. Knipholone, being an anthraquinone derivative, is anticipated to undergo one-electron oxidation and subsequently interact with haem (or other biomolecular targets) thereby inhibiting its tetramerization (or detoxification of haem). Similarly, because of the structural similarity of dianellin and phlorizin, a monoglucosidechalcone, its anti-malarial mechanism of action could be due to inhibition of the solute transporter of the 
host cell membrane induced by the parasite invasion [53, 54].

\section{Molecular docking study}

To get further insight on the mechanism of action of the isolated compounds and to study their binding interaction and identify hypothetical binding motifs, a docking study of knipholone, dianellin and the standard antimalarial drugs chloroquine and artemisinin were carried out on two crystal structures of target enzymes. The two Plasmodium enzymes were plasmepsin II (PDB code 4cku) involved in haemoglobin metabolism by the parasite, and $P$. falciparum 1-lactate dehydrogenase (pfLDH) (PDB code 1ldg) involved in glycolysis (or glucose metabolism of the parasite) [55-57]. There is a strong suggestion that haemoglobin digesting enzymes found in the food vacuole of the Plasmodium and pfLDH are potential anti-malarial chemotherapeutic targets for chloroquine and related aminoquionlones, anthraquinones and other oxidative phenolic compounds [58-63]. Gossypol and other phenolic compounds were also found to be pfLDH inhibitors $[64,65]$. Besides, chloroquine has been found to bind to the cofactor (NADH) binding site of pfLDH acting as a competitive inhibitor [66].

The binding modes of P2FE-400, a designed inhibitor of plasmepsin II, knipholone and chloroquine to plasmepsin II are shown in Fig. 4. P2FE-400 showed the highest and strongest affinity for the aspartic protease, plasmepsin II, with the HYDE score of $-38.3 \mathrm{~kJ} / \mathrm{mol}$. The aspartic protease plasmepsin II has two aspartic acid residues Asp34 and Asp214 (the catalytic dyad) that serve as proton donors and acceptors, respectively, in the amide hydrolysis of peptide bonds in proteins. As shown in the current study and also described by Jaudzems et al. [67], P2FE400 forms four hydrogen bonds with the catalytic dyad (Asp34 and Asp214), Val78 and Ser218 amino acid residues. Chloroquine showed a comparable binding affinity with an estimated HYDE score of $-19.7 \mathrm{~kJ} / \mathrm{mol}$. The $\mathrm{Cl}$ substituent of chloroquine was found to be unsuitable for binding in the hydrophobic cavity of plasmepsin II. Chloroquine forms hydrogen bonds with Gly36 and Val78 amino acid residues. Knipholone and dianellin showed weak binding interaction with HYDE score of -6.0 and $-4.2 \mathrm{~kJ} / \mathrm{mol}$, respectively. Nonetheless, knipholone forms two hydrogen bonds with one of the catalytic dyad (Asp214) and Val78 amino acid residues.

The binding modes of knipholone and chloroquine to pfLDH binding site are shown in Fig. 5. Knipholone $(-29.1 \mathrm{~kJ} / \mathrm{mol})$ showed stronger binding interaction with pfLDH than chloroquine $(-24.7 \mathrm{~kJ} / \mathrm{mol})$. Knipholone forms hydrogen bonds with Ile54 and Val98 amino acid residues. Its carbonyl oxygen (at C-9) and hydroxyl group in ring $\mathrm{A}$ (at $\mathrm{C}-1$ ) of the anthraquinone moiety, and the carbonyl oxygen (at $\mathrm{C}-3^{\prime}$ ) of the phloroglucinol moiety together with the ortho and para hydroxyl groups (at $C-1^{\prime}$ and $C-4^{\prime}$ ) are not favourable for binding. From the experimental data, there were seven hydrogen bonds in pfLDH-NADH complex, of which four are observed in this study [68]. Chloroquine on its part showed two hydrogen bonds with Asp53 and Gly99 amino acid residues. One of the $\mathrm{N}$-ethyl groups of chloroquine is not needed in the hydrophilic binding sites. Moreover, the actual pfLDH-chloroquine complex also showed two hydrogen bonds with Glu122 and Gly99 [66]. In contrast, dianellin did not show binding interaction with pfLDH.

\section{Conclusion}

In conclusion, the rhizome extracts of $K$. folosia possess in vivo anti-malarial effect against $P$. berghei in mice. This finding in conjunction with the safety profile obtained from the acute oral toxicity results support the traditional claim of the plant for the treatment of malaria. The current molecular docking study also identified the binding motifs of the isolated compounds showing that knipholone interact with important amino acid residues in the binding site of the target enzymes.

\section{Supplementary Information}

The online version contains supplementary material available at https://doi. org/10.1186/s12936-020-03552-7.

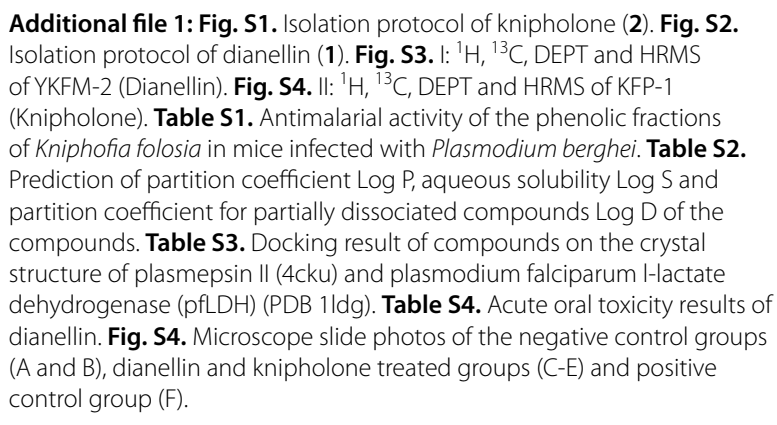

\section{Abbreviations}

AAU: Addis Ababa University; EHNRI: Ethiopian Health Nutrition and Research Institute; $\mathrm{ED}_{50}$ : Median effective dose; i.p: Intraperitoneally; $\mathrm{NADH}$ : Nicotinamide adenine dinucleotide; pfLDH: Plasmodium falciparum L-lactate dehydrogenase; p.i: Post-infection; PTLC: Preparative thin layer chromatography; PDB: Protein Data Bank; SoP: School of Pharmacy.

\section{Acknowledgements}

YA would like to acknowledge the Office of Graduate Studies and Research of Addis Ababa University for the sponsorship. The authors would like to express their gratitude to Professor Sebsebe Demissew, the National Herbarium, AAU, for identification of the plant material.

\section{Authors' contributions}

YA conceived the study, collected the plant material, conducted the laboratory experiments and prepared the manuscript. DB and KA were involved in the analysis and interpretation of experimental results, and edited the 
manuscript. ST run the NMR experiment and edited the manuscript. All authors read and approved the final manuscript.

\section{Funding}

This study was supported by the School of Graduate Studies of Addis Ababa University, research grant.

\section{Availability of data and materials}

The following are given in the supplementary figures or tables: Isolation protocols of compounds $\mathbf{1}$ and $\mathbf{2}$ and their NMR and HRMS spectra; Summaries of anti-malarial activity of the phenolic fractions along with acute toxicity results of one of the isolated compounds; Predicted physicochemical properties of the standard drugs, isolated compounds and P2FE-400; Summaries of the docking results; and Microscope slide photos.

\section{Ethics approval and consent to participate}

All the animal study procedures followed were reviewed and approved by the Institutional Review Board of the SoP, College of Health Sciences, AAU. The mice were handled in accordance with the Guide for the Care and Use of Laboratory Animals [23].

\section{Consent for publication}

Not applicable.

\section{Competing interests}

The authors declare no conflict of interest.

Received: 16 September 2020 Accepted: 12 December 2020

Published online: 01 January 2021

\section{References}

1. Cowman AF, Healer J, Marapana D, Marsh K. Malaria: biology and disease. Cell. 2016:167:610-24.

2. WHO. World malaria report 2019. Geneva: World Health Organization; 2019.

3. Snow RW, Sartorius B, Kyalo D, Maina J, Amratia P, Mundia CW, et al. The prevalence of Plasmodium falciparum in sub-Saharan Africa since 1900. Nature. 2017:550:515-8.

4. Farooq U, Mahajan RC. Drug resistance in malaria. J Vector Borne Dis. 2004:41:45-53.

5. WHO. World malaria report. Country profile: Ethiopia. Geneva: World Health Organization; 2017. p. 2017.

6. Tadesse F, Fogarty AW, Deressa W. Prevalence and associated risk factors of malaria among adults in East Shewa Zone of Oromia Regional State, Ethiopia: a cross-sectional study. BMC Public Health. 2018;18:25.

7. Achan J, Talisuna AO, Erhart A, Yeka A, Tibenderana JK, Baliraine FN, et al. Quinine, an old antimalarial drug in a modern world: role in the treatment of malaria. Malar J. 2011;10:144.

8. White NJ, Hien TT, Nosten FH. A brief history of Qinghaosu. Trends Parasitol. 2015;31:607-10

9. Saxena S, Pant N, Jain DC, Bhakuni RS. Antimalarial agents from plant sources. Curr Sci. 2003;85:1314-29.

10. Bero J, Frédérich M, Quetin-Leclercq J. Antimalarial compounds isolated from plants used in traditional medicine. J Pharm Pharmacol. 2009:61:1401-33.

11. Ntie-Kang F, Onguéné PA, Lifongo LL, Ndom JC, Sippl W, Mbaze LM. The potential of antimalarial compounds derived from African medicinal plants, part II: a pharmacological evaluation of non-alkaloids and nonterpenoids. Malar J. 2014;13:81.

12. Dahlgren RMT, Clifford HT, Yeo PF. The families of the monocotyledons. Berlin: Springer-Verlag; 1985.

13. Whitehouse C. Asphodelaceae. In: Beentje HJ, ed. Flora of Tropical East Africa. Rotterdam: Balkema Publ.; 2002.

14. Demissew S, Nordan I. Aloes and lilies of Ethiopia and Eritrea. Addis Ababa: Shama Books; 2010. p. 113-25.

15. Abate G. Etse Debdabe: Ethiopian Traditional Medicine. Demissew S, ed. Addis Ababa: Addis Ababa University Press; 1989. p. 99-183.

16. Wube AA, Bucar F, Asres K, Gibbons S, Rattray L, Croft SL. Antimalarial compounds from Kniphofia foliosa roots. Phytother Res. 2005;19:472-6.
17. Abdissa N, Akala HM, Heydenreich M, Midiwo JO, Ndakala A, Yenesew A. Knipholone cyclooxanthrone and an anthraquinone dimer with antiplasmodial activities from the roots of Kniphofia foliosa. Phytochem Lett. 2013;6:241-5.

18. Endale A, Bisrat D, Animut A, Bucar F, Asres K. In vivo antimalarial activity of a labdane diterpenoid from the leaves of Otostegia integrifolia Benth. Phytother Res. 2013;27:1805-9.

19. Girma B, Bisrat D, Asres K. Antimalarial evaluation of the leaf latex of Aloe citrina and its major constituent. Anc Sci Life. 2015;34:142-6.

20. Teka T, Bisrat D, Yeshak MY, Asres K. Antimalarial activity of the chemical constituents of the leaf latex of Aloe pulcherrima Gilbert and Sebsebe. Molecules. 2016;2016(21):1415.

21. OECD. Guidelines for testing of chemicals. Guideline 425: Acute oral toxicity. Paris, France: The Organization of Economic Co-operation and Development; 2008.

22. Vennerstrom JL, Arbe-Barnes S, Brun R, Charman SA, Chiu FCK, Chollet J, et al. Identification of an antimalarial synthetic trioxolane drug development candidate. Nature. 2004;430:900-4.

23. Fentahun S, Makonnen E, Awas T, Giday M. In vivo antimalarial activity of crude extracts and solvent fractions of leaves of Strychnos mitis in Plasmodium berghei infected mice. BMC Complement Altern Med. 2017;17:13.

24. National Institute of Health Guidelines for the Care and Use of Laboratory Animals and National Institutes of Health, Office of Science and Health Reports. Guide for care and use of laboratory animals 83-23. Bethesda, Md, USA: Office of Science and Health Reports, Department of Health and Human Services; 1996.

25. Waako PJ, Gumede B, Smith P, Folb PI. The in vitro and in vivo antimalarial activity of Cardiospermum halicacabum L. and Momordica foetida Schumch. Et Thonn. J Ethnopharmacol. 2005;99:137-43.

26. Hilou A, Nacoulma OG, Guiguemde TR. In vivo antimalarial activities of extracts from Amaranthus spinosus L. and Boerhaavia erecta L. in mice. J Ethnopharmacol. 2006;103:236-40.

27. Peters W. Drug resistance in Plasmodium berghei Vincke and Lips, 1948. I Chloroquine resistance. Exp Parasitol. 1965;17:80-9.

28. Tamiru W, Engidawork E, Asres K. Evaluation of the effects of $80 \%$ methanolic leaf extract of Caylusea abyssinica (Fresen.) Fisch. \& Mey on glucose handling in normal, glucose loaded and diabetic rodents. BMC Complement Altern Med. 2012;12:151.

29. Ancelin ML, Calas ML, Bonhoure A, Herbute S, Vial HJ. In vivo antimalaria activities of mono-and bis quaternary ammonium salts interfering with Plasmodium phospholipid metabolism. Antimicrob Agents Chemother. 2003:47:2598-605.

30. Schneider N, Hindle S, Lange G, Klein R, Albrecht J, Briem H, et al. Substantial improvements in large-scale redocking and screening using the novel HYDE scoring function. J Comput Aided Mol Des. 2012;26:701-23.

31. Schneider N, Lange G, Hindle S, Klein R, Rarey M. A consistent description of hydrogen bond and dehydration energies in protein-ligand complexes: methods behind the HYDE scoring function. J Comput Aided Mol Des. 2013:27:15-29.

32. Cichewicz RH, Nair MG. Isolation and characterization of stelladerol, a new antioxidant naphthalene glycoside, and other antioxidant glycosides from edible daylily (Hemerocallis) flowers. J Agric Food Chem. 2002;50:87-91.

33. Dias DA, Silva CA, Urban S. Naphthalene aglycones and glycosides from the Australian medicinal plant, Dianella callicarpa. Planta Med. 2009;75:1442-7.

34. Cichewicz RH, Lim K-C, McKerrow JH, Nair MG. Kwanzoquinones A-G and other constituents of Hemerocallis fulva 'Kwanzo' roots and their activity against the human pathogenic trematode Schistosoma mansoni. Tetrahedron. 2002:58:8597-606.

35. Bezabih M, Abegaz BM. 4'-Demethyl knipholone from aerial parts of Bulbine capitata. Phytochemistry. 1998;48:1071-3.

36. Dagne E, Steglich W. Knipholone: a unique anthraquinone derivative from Kniphofia foliosa. Phytochemistry. 1984:23:1729-31.

37. Geremedhin G, Bisrat D, Asres K. Isolation, characterization and in vivo antimalarial evaluation of anthrones from the leaf latex of Aloe percrassa Todaro. J Nat Remedies. 2014;14:119-25.

38. Deharo E, Bourdy G, Quenevo C, Muñoz V, Ruiz G, Sauvain M. A search for natural bioactive compounds in Bolivia through a multidisciplinary approach. Part V. Evaluation of the antimalarial activity of plants used by the Tacana Indians. J Ethnopharmacol. 2001;77:91-8. 
39. Abosi AO, Raseroka BH. In vivo antimalarial activity of Vernonia amygdalina. Br J Biomed Sci. 2003;60:89-91.

40. Deressa T, Mekonnen Y, Animut A. In vivo antimalarial activities of Clerodendrum myricoides, Dodonea angustifolia and Aloe debrana against Plasmodium berghei. Ethiop J Health Dev. 2010;24:25-9.

41. Liu Y, Murakami N, Ji H, Abreu P, Zhang S. Antimalarial flavonol glycosides from Euphorbia hirta. Pharm Biol. 2007:45:278-81.

42. Bankole AE, Adekunlel AA, Sowemimo AA, Umebese CE, Abiodun O, Gbotosho GO. Phytochemical screening and in vivo antimalarial activity of extracts from three medicinal plants used in malaria treatment in Nigeria. Parasitol Res. 2016;115:299-305.

43. Alson SG, Jansen $\mathrm{O}$, Cieckiewicz E, Rakotoarimanana $\mathrm{H}$, Rafatro H, Degotte $\mathrm{G}$, et al. In vitro and in vivo antimalarial activity of caffeic acid and some of its derivatives. J Pharm Pharmacol. 2018;70:1349-56.

44. Bringmann G, Menche D, Bezabih M, Abegaz BM, Kaminsky R. Antiplasmodial activity of knipholone and related natural phenylanthraquinones. Planta Med. 1999;65:757-8.

45. Abegaz BM, Bezabih M, Msuta T, Brun R, Menche D, Mühlbacher J, et al. Gaboroquinones A and B and 4'-O-demethylknipholone-4'-O-betaD-glucopyranoside, phenylanthraquinones from the roots of Bulbine frutescens. J Nat Prod. 2002;65:1117-21.

46. Dai Y, Harinantenaina L, Bowman JD, Da Fonseca IO, Brodie PJ, Goetz M, et al. Isolation of antiplasmodial anthraquinones from Kniphofia ensifolia, and synthesis and structure-activity relationships of related compounds. Bioorg Med Chem. 2014;22:269-76.

47. Sema DK, Lannang AM, Tatsimo SJ, Yousuf S, Zoufoud D, Iqbal U, Wansi $J \mathrm{D}$, et al. New indane and naphthalene derivatives from the rhizomes of Kniphofia reflexa Hutchinson ex Codd. Phytochem Lett. 2018;26:78-82.

48. Winter RW, Cornell KA, Johnson LL, Ignatushchenko MV, Hinrichs DJ, Riscoe MK. Potentiation of the antimalarial agent rufigallol. Antimicrob Agents Chemother. 1996;40:1408-11.

49. Hernández-Medel MR, Pereda-Miranda R. Cytotoxic anthraquinone derivatives from Picramnia antidesma. Planta Med. 2002:68:556-8.

50. François G, Steenackers T, Assi LA, Steglich W, Lamottke K, Holenz J, et al. Vismione $\mathrm{H}$ and structurally related anthranoid compounds of natural and synthetic origin as promising drugs against the human malaria parasite Plasmodium falciparum: structure-activity relationships. Parasitol Res. 1999:85:582-8.

51. Ignatushchenkoa MV, Winter RW, Bächinger HP, Hinrichs DJ, Riscoe MK. Xanthones as antimalarial agents; studies of a possible mode of action. FEBS Lett. 1997;409:67-73.

52. Ziegler J, Linck R, Wright DW. Heme aggregation inhibitors: antimalarial drugs targeting an essential biomineralization process. Curr Med Chem. 2001:8:171-89.

53. Kutner S, Breuer WV, Ginsburg H, Cabantchik ZI. On the mode of action of phlorizin as an antimalarial agent in in vitro cultures of Plasmodium falciparum. Biochem Pharmacol. 1987;36:123-9.

54. Ehrenkranz JRL, Lewis NG, Kahn CR, Roth J. Phlorizin: a review. Diabetes Metab Res Rev. 2005:21:31-8.
55. Bazik DJ, Fox BA, Gonyer K. Expression of Plasmodium falciparum lactate dehydrogenase in Escherichia coli. Mol Biochem Parasitol. 1993;59:155-66.

56. Silva AM, Lee AY, Gulnik SV, Majer P, Collins J, Bhat TN, et al. Structure and inhibition of plasmepsin II, a hemoglobin-degrading enzyme from Plasmodium falciparum. Proc Natl Acad Sci USA. 1996:93:10034-9.

57. Nöteberg D, Hamelink E, Hultén J, Wahlgren M, Vrang L, Samuelsson B, et al. Design and synthesis of plasmepsin I and plasmepsin II inhibitors with activity in Plasmodium falciparum-infected cultured human erythrocytes. J Med Chem. 2003:46:734-46.

58. Slater AF. Chloroquine: mechanism of drug action and resistance in Plasmodium falciparum. Pharmacol Ther. 1993;1993(57):203-35.

59. Haque TS, Skillman AG, Lee CE, Habashita H, Gluzman IY, Ewing TJA, et al. Potent, low-molecular-weight non-peptide inhibitors of malarial aspartyl protease plasmepsin II. J Med Chem. 1999;42:1428-40.

60. Choi SR, Pradhan A, Hammond NL, Chittiboyina AG, Tekwani BL, Avery MA. Design, synthesis, and biological evaluation of Plasmodium falciparum lactate dehydrogenase inhibitors. J Med Chem. 2007;50:3841-50.

61. D'Alessandro S, Silvestrini F, Dechering K, Corbett Y, Parapini S, Timmerman $M$, et al. A Plasmodium falciparum screening assay for anti-gametocyte drugs based on parasite lactate dehydrogenase detection. J Antimicrob Chemother. 2013;68:2048-58.

62. Tiwari HK, Kumar P, Jatana N, Kumar K, Garg S, Narayanan L, et al. In vitro antimalarial evaluation of piperidine- and piperazine-based chalcones: inhibition of falcipain-2 and plasmepsin II hemoglobinases activities from Plasmodium falciparum. ChemistrySelect. 2017:2:7684-90.

63. Cheuka PM, Dziwornu G, Okombo J, Chibale K. Plasmepsin inhibitors in antimalarial drug discovery: medicinal chemistry and target validation (2000 to present). J Med Chem. 2010;63:4445-67.

64. Conners R, Schambach F, Read J, Cameron A, Sessions RB, Vivas L, et al. Mapping the binding site for gossypol-like inhibitors of Plasmodium falciparum lactate dehydrogenase. Mol Biochem Parasitol. 2005;142:137-48.

65. Megnassan E, Keita M, Bieri C, Esmel A, Frecer V, Miertus S. Design of novel dihydroxynaphthoic acid inhibitors of Plasmodium falciparum lactate dehydrogenase. Med Chem. 2012;8:970-84.

66. Read JA, Wilkinson KW, Tranter R, Sessions RB, Brady RL. Chloroquine binds in the cofactor binding site of Plasmodium falciparum lactate dehydrogenase. J Biol Chem. 1999;274:10213-8.

67. Jaudzems K, Tars K, Maurops G, Ivdra N, Otikovs M, Leitans J, et al. Plasmepsin inhibitory activity and structure-guided optimization of a potent hydroxyethylamine-based antimalarial hit. ACS Med Chem Lett. 2014;5:373-7.

68. Chaikuad A, Fairweather V, Conners R, Joseph-Horne T, Turgut-Balik D, Brady RL. Structure of lactate dehydrogenase from Plasmodium vivax: complexes with NADH and APADH. Biochemistry. 2005;44:16221-8.

\section{Publisher's Note}

Springer Nature remains neutral with regard to jurisdictional claims in published maps and institutional affiliations.
Ready to submit your research? Choose BMC and benefit from:

- fast, convenient online submission

- thorough peer review by experienced researchers in your field

- rapid publication on acceptance

- support for research data, including large and complex data types

- gold Open Access which fosters wider collaboration and increased citations

- maximum visibility for your research: over 100M website views per year

At $\mathrm{BMC}$, research is always in progress.

Learn more biomedcentral.com/submissions 